\title{
Complex Impedance Spectra of a Multi-layer Chip Coil Using Li-Zn-Cu Ferrite
}

\author{
M. Naoe, T. Nakamura*, and Y. Yamada* \\ Technical Development Center, KOA Corporation, 14016-149 Naka-Minowa, Minowa, Kami-Ina, Nagano 399-4697, Japan \\ *Graduate School of Engineering, University of Hyogo, 2167 Shosha, Himeji 671-2201, Japan
}

\begin{abstract}
Multi-layer chip coils were fabricated by the green sheet technique using polycrystalline $\mathrm{Li}-\mathrm{Zn}-\mathrm{Cu}$ ferrite or $\mathrm{Ni}-\mathrm{Zn}-\mathrm{Cu}$ ferrite, and their complex impedance spectra were analyzed with the help of numerical calculation. When $\mathrm{Ni}-\mathrm{Zn}-\mathrm{Cu}$ ferrite is used, the complex impedance spectra of multi-layer chip coils are very sensitive to residual stress, and they deviate markedly from the values calculated by using complex permeability, permittivity, and the chip coil dimensions. On the other hand, it was found that the complex impedance of a multi-layer chip coil using $\mathrm{Li}-\mathrm{Zn}-\mathrm{Cu}$ ferrite may be determined from the complex permeability and permittivity of the polycrystalline $\mathrm{Li}-\mathrm{Zn}-\mathrm{Cu}$ ferrite as well as the chip coil dimensions. Consequently, the use of $\mathrm{Li}-\mathrm{Zn}-\mathrm{Cu}$ ferrite made it easy for us to design the complex impedance of a multi-layer chip coil. It is that the difference is related to the magnetostriction of polycrystalline ferrite. Hence, it was clarified that polycrystalline $\mathrm{Li}-\mathrm{Zn}-\mathrm{Cu}$ ferrite has a great advantage for multi-layer chip coil applications.
\end{abstract}

Key words: $\mathrm{Li}-\mathrm{Zn}-\mathrm{Cu}$ ferrite, complex permeability and permittivity, multi-layer chip coil, magnetostriction, residual stress, complex impedance

\section{Li-Zn-Cu フェライトを用いた積層コイルの複素インピーダンス・スペクトル}

\author{
直江正幸・中村龍哉* • 山田義博* \\ KOA 株式会社 技創りセンター, 長野県上伊那郡箕輪町中箕輪 14016-149 (广 399-4697) \\ *兵庫県立大学大学院工学研究科, 姫路市書写 2167 (广 671-2201)
}

\section{1. はじめに}

我々は，これまでに $\mathrm{Li}-\mathrm{Zn}$ および $\mathrm{Li}-\mathrm{Zn}-\mathrm{Cu}$ フェライト 多結晶体の高周波透磁率スペクトルについて解析を行い, これらのフェライトが，スピネルフェライトの中でも大き なスヌーク積を示すことを明らかにした ${ }^{1,2)}$.また，グリー ンシート工法による $\mathrm{Li}-\mathrm{Zn}-\mathrm{Cu}$ フェライトを用いた積層コ イルの作製を検討してきた ${ }^{3)}$.

通常，低温で容易に合成・焼結が可能であり，かつ高周 波特性に優れている理由から, 積層電子部品用の磁性材料 には $\mathrm{Ni}-\mathrm{Zn}-\mathrm{Cu}$ フェライト多結晶体が広く用いられている. しかし， Ni の発ガン可能性などが一部で指摘されている. EU 諸国による RoHS および WEEE 指令や, 日本国内の PRTR 法などの法令を考慮すると, $\mathrm{Ni}$ 系フェライトは近い 将来使用規制対象となりうるので, $\mathrm{Ni}$ フリーの積層部品用 高周波フェライト材料が期待されている. 加えて, Ni を含 むフェライトは, 比較的大きな磁歪定数を有しているため, 透磁率が応力の影響を受けやすいことが知られている ${ }^{4-7)}$. そのため, このフェライトを用いて積層部品を作製すると, フェライトと内部導体との同時焼成後の冷却過程で, これ らの熱膨張係数の差により部品内部に残留応力が発生, 逆 磁歪効果により, 部品におけるフェライトの実効的透磁率 が見積もりよりも低下寸る。内部導体パターン形成に用い る Ag ペーストを改良し, 焼結収縮挙動もしくは熱膨張挙 動を制御することで残留応力を低減するなどの工夫が各研 究者のノウハウになっているが 8), Q 值や定格電流值の確
保などの課題を考慮すると限度があり，残留応力を皆無に できないのが現実である.このため，フェライト本来の透 磁率を部品の性能に直接反映できないことが部品設計上の 大きな問題点となっている. $\mathrm{Li}-\mathrm{Zn}-\mathrm{Cu}$ フェライトを用いた 積層コイルの複素インピーダンス評価した結果，ほぼ同じ 初透磁率を有する $\mathrm{Ni}-\mathrm{Zn}-\mathrm{Cu}$ フェライトを用いた同型のそ れよりも，大きな絶対值を有していることがわかった。こ れは, $\mathrm{Li}$ 系フェライトの磁歪定数, 例えば ${ }_{111}$ が+2.3〜 $+4.5 \times 10^{-6}$ であり, $\mathrm{Ni}$ 系フェライト $\left(-21 \sim-26 \times 10^{-6}\right)$ と 比較して約 $20 \%$ 以下の小さな值を有することから ${ }^{9)}$, 用い た $\mathrm{Li}-\mathrm{Zn}-\mathrm{Cu}$ フェライト多結晶体の磁歪定数が $\mathrm{Ni}-\mathrm{Zn}-\mathrm{Cu}$ フ エライトと比較して小さく, 複素透磁率が応力によって低 下しにくいことに起因していると予測された.

これまで，応力によるフェライトの複素透磁率の変化は 次のような方法で検討されていた。 フェライト多結晶体の リングコアを用いた巻線型トロイダルコイルに外部から応 力を加えて，初透磁率を測定し，その変化を調心゙るもので あった ${ }^{4,10)}$.しかし, 積層コイル内部では, 三次元形状コ イルの存在により, 応力のベクトルが場所によって異なり 不均一なものである ${ }^{8)}$. 即ち, 透磁率の変化率は一様でな く, 上記トロイダルコイルの場合とは異なるものと考えら れる. 従って, このような結果から, 応力が対象のフェラ イト多結晶体を用いた積層部品の複素インピーダンスに及 ぼす影響にまで議論を発展させることは困難である。

本研究では，フェライト多結晶体の複素透磁率スペクト ルとコイルの形状・寸法から数值計算を用いて積層部品の 
複素インピーダンスを算出し，これと計測器による実測值 を比較するマクロ的手法で, 応力による複素インピーダン スの変化を求めた． $\mathrm{Li}-\mathrm{Zn}-\mathrm{Cu}$ フェライトおよび $\mathrm{Ni}-\mathrm{Zn}-\mathrm{Cu}$ フェライトを用いて同条件・同形状の積層コイルを作製し, 複素インピーダンスを測定・数值解析して比較を行った。 その結果, 積層部品用の磁性材料としての $\mathrm{Li}-\mathrm{Zn}-\mathrm{Cu}$ フェ ライトの優位性が明らかになったのでここに報告する。

\section{2. 実験方法}

\section{1 フェライト積層コイルの作製とインピーダンスの測定}

フェライト粉末は，通常の固相反応法により作製した。 $\mathrm{Li}_{2} \mathrm{CO}_{3}, \mathrm{ZnO}, \mathrm{CuO}, \mathrm{Fe}_{2} \mathrm{O}_{3}, \mathrm{Mn}_{3} \mathrm{O}_{4}$ および $\mathrm{NiO}$ の高純度微 粉末を出発原料として用い, これらの原料を, $\mathrm{Li}-\mathrm{Zn}-\mathrm{Cu}$ フ エライトは $\mathrm{Li}_{0.227} \mathrm{Zn}_{0.151} \mathrm{Cu}_{0.404}\left(\mathrm{Fe}_{0.9} \mathrm{Mn}_{0.1}\right)_{2.203} \mathrm{O}_{4}$ 、一方 $\mathrm{Ni}-\mathrm{Zn}-\mathrm{Cu}$ フェライトでは $\mathrm{Ni}_{0.78} \mathrm{Zn}_{0.09} \mathrm{Cu}_{0.20} \mathrm{Fe}_{1.93} \mathrm{O}_{4}$ となる

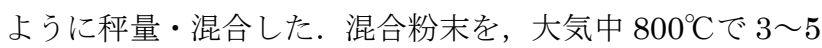
時間仮焼成し，この粉末を湿式ボールミルにより平均粒子 径が $1.1 \mu \mathrm{m}$ となるよう粉砕してフェライト粉末を調製した。 これらのフェライト粉末を用いて, グリーンシート工法に より積層コイルを作製した。 外寸が約 $1.0 \mathrm{~mm}(\mathrm{~L}) \times$ $0.5 \mathrm{~mm}(\mathrm{~W}) \times 0.5 \mathrm{~mm}(\mathrm{t})$ のフェライトチップ内部に, 5.5 タ ーンのコイルを内蔵するよう積層コイルを設計した。 スク リーン印刷法により, $\mathrm{Ag}$ ペーストを用いて電極パターンを 形成した。 パターン形成後, 積層工程を経て大気中 $890^{\circ} \mathrm{C}$ で 2 時間焼成した。積層コイル部品の複素インピーダンス は，インピーダンス・アナライザ(Agilent Technologies, $\mathrm{E} 4991 \mathrm{~A})$ を用い, 周波数 $1 \mathrm{MHz} \sim 3 \mathrm{GHz}$ の範囲で測定した.

\section{2 多結晶フェライトの材料定数の評価}

内部コイルを形成しない以外は積層コイルの作製方法と 同じ条件で, グリーンシート工法により約 $10 \times 10 \times 1(\mathrm{~mm})$ の $\mathrm{Li}-\mathrm{Zn}-\mathrm{Cu}$ フェライトおよび $\mathrm{Ni}-\mathrm{Zn}-\mathrm{Cu}$ フェライト多結晶 体を作製した。これらを超音波加工機(日本電子工業, UM-300C)を用いて, 外形 $7 \mathrm{~mm}$, 内径 $3 \mathrm{~mm}$, 厚み $1 \mathrm{~mm}$ のトロイダルコアに加工した．インピーダンス・アナライ ザ(Hewlett Packard, 4194A)およびネットワーク・アナラ イザ(Hewlett Packard, 8753C)を用いて複素透磁率スペク トルを測定した(測定周波数 $1 \mathrm{MHz} \sim 3 \mathrm{GHz}$ ). フェライト多 結晶体の導電率および誘電率を測定するために, 直径約 $10 \mathrm{~mm}$, 厚み約 $3 \mathrm{~mm}$ の円盤状の焼結体試料を作製した. 超高抵抗計(ADVANTEST, R8340A)を用いて直流抵抗值 (電圧印可： $50 \mathrm{~V}, 1 \mathrm{~min}$ ), LCR メータ(Hewlett Packard, $4284 \mathrm{~A}$ )を用いて静電容量(測定周波数 $1 \mathrm{MHz}$ )を測定し, 試 料寸法から導電率および誘電率を算出した.

\section{3 複素インピーダンスの数值計算}

複素インピーダンスの計算は, 有限要素法に基づく 3 次 元電磁界シミュレーションツール(Ansoft Corporation, HFSS Ver.9.2.1)を用いて行った 11,12)。作製したそれぞれ のコイルの外寸を測定後, 切削して SEM(日立製作所, S-3000N)により内部コイルの寸法を計測、3D モデル化し

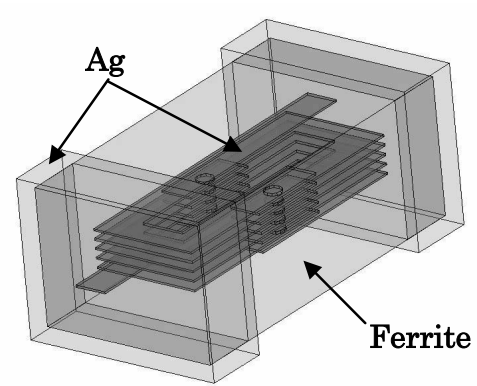

Fig. 1 The 3D model of multi-layer chip coil for 3D electromagnetic simulation

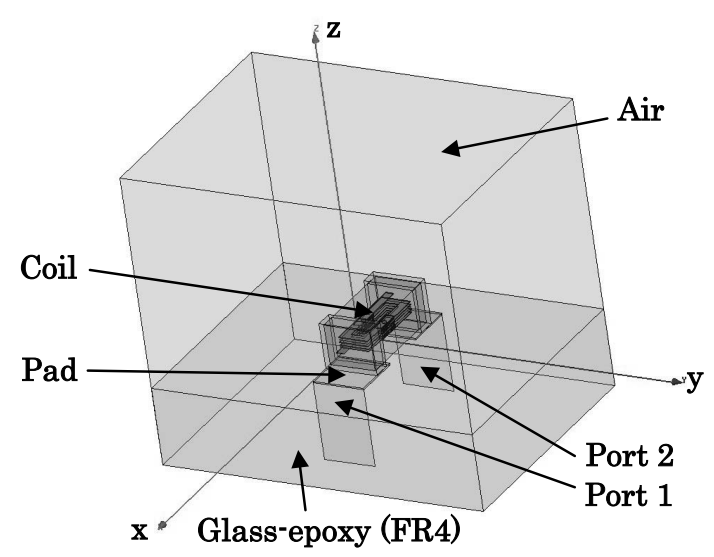

Fig. 2 The mesh field for simulation

た. Fig. 1 は，その $3 \mathrm{D}$ モデルであり、それぞれの部位に 予め材料特性(複素透磁率, 複素誘電率, フェライトおよび $\mathrm{Ag}$ 導体の導電率)の周波数特性を与える.フェライトは磁 気飽和しないものとし, 異方性は与えていない. Fig. 2 は、 $3 \mathrm{D}$ モデルを含むメッシュ領域である.この周囲を無限の完 全導体とすることで遮蔽した.メッシュ領域のサイズは,

Fig. 2 における奥行き $(\mathrm{x}$ 方向 $) \times$ 幅 $(\mathrm{y}$ 方向 $) \times$ 高さ $(\mathrm{z}$ 方向 $)$ が $4 \times 6 \times 6 \mathrm{~mm}$ で, 積層コイルはそのほぼ中央に位置する. この比較的小さなメッシュ領域でも電磁界分布がほぼ収ま り，これ以上領域を大きくしても計算結果に有意差が見ら れないことを確認した．実測された部品寸法による 3D モ デルでは厳密には幾何学的対称面や周期性が存在しないた め, 今回は対称境界および周期境界の設定を行っていない. 回路の終端負荷インピーダンスは $50 \Omega$ とした. Port 1 から 1 周期の正弦波電圧を入力した。正弦波電圧の周波数は $30 \mathrm{MHz}$ とした. この $1 / 3$ 波長の大きさの初期メッシュが, 自動的に各頂点と稜線の中点に節点を有する四面体として 生成する. 各辺の長さは最適化されるためそれぞれ異なる. 各節点でメッシュ内部の磁界や電界のベクトル量を補間, Maxwell の方程式に基づく行列方程式を解いて得た電磁界 分布から, Port 1-2 間の $\mathrm{S}$ パラメータが計算される. 定常 解の計算のため電磁界の時間変化は省略されている.この 計算が収束するまで, メッシュ数の増加率を $20 \%$ としてメ ッシュ細分化と計算を反復させた． S パラメータの計算残 差が $2 \%$ 以下となったときに収束したと判定させた.このと き, 積層コイル内部などの電磁界の変位が大きい部位で選 
択的にメッシュが細分化される。一方，部品から十分離れ た部位では電磁界の分布がほとんどないため, メッシュの 細分化はあまり進行しない. 反復回数上限は 20 回とした. その結果, 今回のメッシュ総数は約 2 万個であった. 複素 インピーダンスは, $\mathrm{S}$ パラメータから計算された. 細分化 が完了したメッシュ構造を用いて, 掃引モードにより $1 \mathrm{MHz}$ から $1 \mathrm{GHz}$ までの複素インピーダンス・スペクトル を得た。これら応力情報を含まない計算值と, 含まれるイ ンピーダンス・アナライザによる実測值を比較することで, 応力が部品の複素インピーダンスに及ぼす影響を評価した。

\section{3. 実験結果}

\section{1 多結晶フェライトの複素透磁率スペクトル}

$\mathrm{Ni}-\mathrm{Zn}-\mathrm{Cu}$ フェライトおよび $\mathrm{Li}-\mathrm{Zn}-\mathrm{Cu}$ フェライト多結晶 体の複素透磁率スペクトルを Fig. 3 に示す. これらのフェ ライト多結晶体は, 共に典型的な自然共鳴型の複素透磁率 スペクトルを示した. $\mathrm{Ni}-\mathrm{Zn}-\mathrm{Cu}$ フェライトにおいては, 透磁率の絶対值および自然共鳴周波数が, 約 19 および約
$200 \mathrm{MHz}$ であった. 一方, $\mathrm{Li}-\mathrm{Zn}-\mathrm{Cu}$ フェライトでは, 透 磁率の絶対值が約 25 , 自然共鳴周波数が約 $200 \mathrm{MHz}$ であ った. $\mathrm{Ni}-\mathrm{Zn}-\mathrm{Cu}$ フェライトの方が透磁率の絶対值がわず かに小さいこと以外, ほぼ同等の複素透磁率スペクトルを 有していることを確認した。

\section{2 積層コイルの複素インピーダンス・スペクトル}

Fig. 4 に，上記フェライトを用いて作製した積層コイル 部品の複素インピーダンス・スペクトルを示す. $\mathrm{Ni}-\mathrm{Zn}-\mathrm{Cu}$ フェライトを用いたコイルのインダクタンス・スペクトル からは, 低周波数領域でのインダクタンスが約 $170 \mathrm{nH}$ で約 $60 \mathrm{MHz}$ から減衰しており, 交流抵抗成分からは $50 \mathrm{MHz}$ 付 近で急速に大きくなり, 約 $800 \mathrm{MHz}$ で約 $290 \Omega$ の最大值を 示すことが読み取れた. 一方, $\mathrm{Li}-\mathrm{Zn}-\mathrm{Cu}$ フェライトを用い たコイルでの低周波数領域でのインダクタンスは約 $220 \mathrm{nH}$ であり, 約 $100 \mathrm{MHz}$ から減衰した。交流抵抗は, 約 $60 \mathrm{MHz}$ から急速に大きくなり, 約 $550 \mathrm{MHz}$ で最大值約 $440 \Omega$ を示した.

\section{3 積層コイルの複素インピーダンス計算結果}

実測された各積層コイルの外寸、およびTable 1 に示し
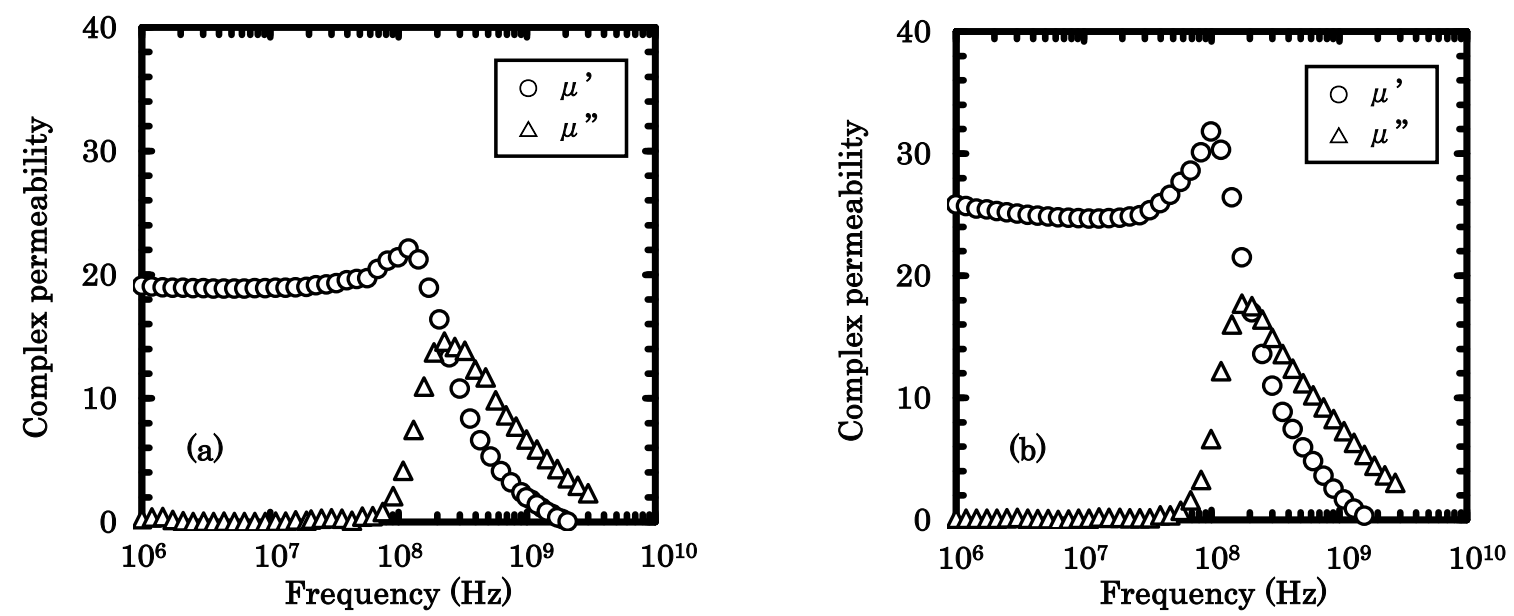

Fig. 3 Complex permeability spectra of polycrystalline ferrites: (a) Ni-Zn-Cu ferrite and (b) $\mathrm{Li}-\mathrm{Zn}-\mathrm{Cu}$ ferrite
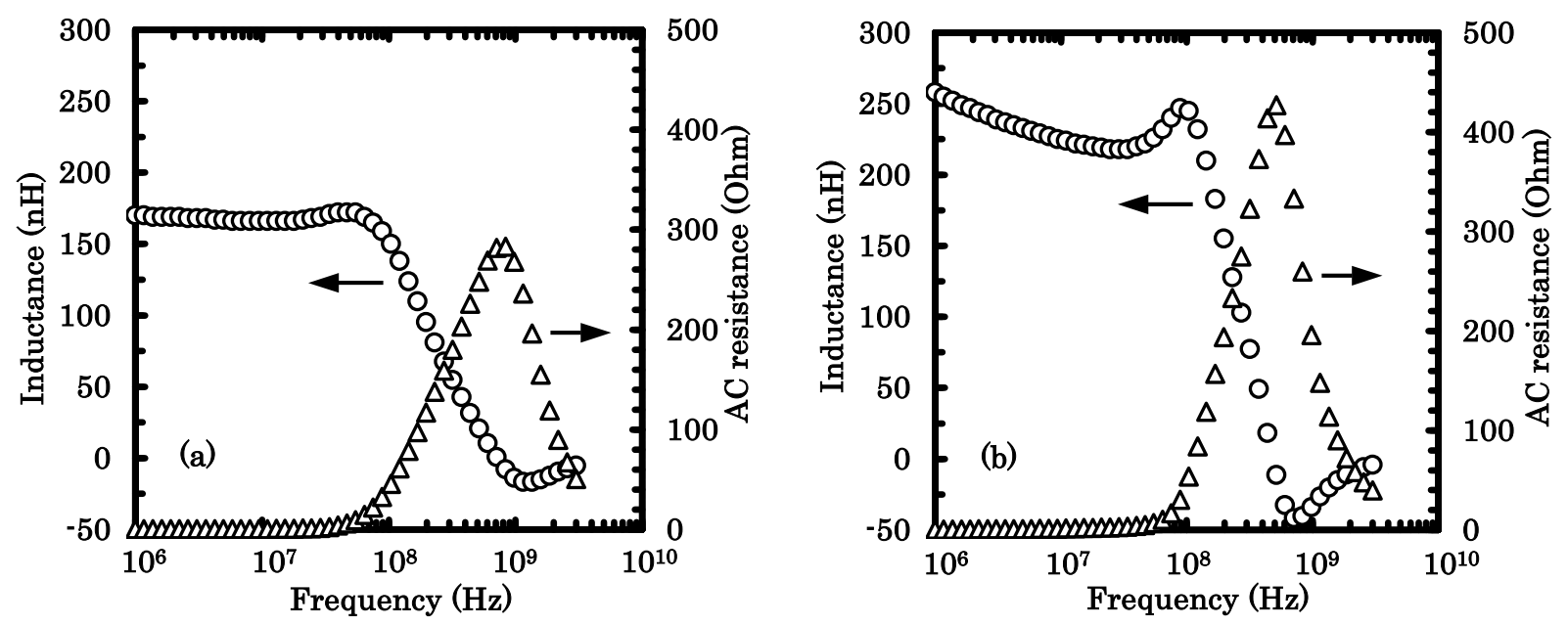

Fig. 4 Inductance and AC resistance of multi-layer chip coils using (a) Ni-Zn-Cu ferrite and (b) $\mathrm{Li}-\mathrm{Zn}-\mathrm{Cu}$ ferrite 
た $\mathrm{Ni}-\mathrm{Zn}-\mathrm{Cu}$ フェライト, およびTable 2 に示した $\mathrm{Li}-\mathrm{Zn}-\mathrm{Cu}$ フェライトの材料定数を用いて, 積層コイルの複素インピ ーダンスを数值計算し, 実測された複素インピーダンスと の比較を行った. フェライトの複素透磁率スペクトルとし て, Fig. 3 に示した測定值を採用した. フェライトの誘電 率については, 絶縁性が十分でないと導電性結晶粒と絶縁 性粒界とのへテロ接合による人工誘電性が現れるが, 導電 性を制御し導電率が小さくなるよう設計されたフェライト の誘電率スペクトルは，ここで対象とした周波数範囲にお いて周波数分散を示さずほぼ一定であることが知られてい る ${ }^{13,14)}$. そこで, 今回用いたフェライト多結晶の複素誘電 率スペクトルについては, 実数部を周波数 $1 \mathrm{MHz}$ における $|\varepsilon \mathrm{r}|$ の測定值で代表させ, さらにその虚数部は 0 とした. フェライトの導電率, $\mathrm{Ag}$ 電極の導電率についてはいずれも 実測值を用いた。

Fig. 5 に， Ni-Zn-Cu および $\mathrm{Li}-\mathrm{Zn}-\mathrm{Cu}$ フェライトを用い た積層コイルのインダクタンスについての数值計算結果を 実測された值と共に示した. Fig. 5(a)より, Ni-Zn-Cuフェ ライトを用いた積層コイルの実測值および計算值のスペク トルは，いずれも低周波領域でインダクタンスがほぼ一定 の值を示し, $100 \mathrm{MHz}$ 付近から低下する特徵を有している. しかし, 両者の值は大きく異なっており，低周波領域のイ ンダクタンスは実測值が計算值よりも約 $30 \mathrm{nH}($ 約 $15 \%$ )小 さいことがわかった. 逆に約 $300 \mathrm{MHz}$ 以上の高周波数領域 においては実測值の方が計算值より大きくなった。

Table 1 Material parameters for 3D simulation of a multi-layer chip coil using $\mathrm{Ni}-\mathrm{Zn}-\mathrm{Cu}$ ferrite

\begin{tabular}{|l|l|}
\hline Complex permeability of ferrite & $\begin{array}{l}\text { Measured values } \\
\text { (Fig. 3a) }\end{array}$ \\
\hline Complex permittivity of ferrite & $13.6+\mathrm{j} 0$ \\
\hline DC conductivity of ferrite & $2.2 \times 10^{-7} \mathrm{~S} / \mathrm{m}$ \\
\hline DC conductivity of Ag electrode & $4.4 \times 10^{7} \mathrm{~S} / \mathrm{m}$ \\
\hline
\end{tabular}

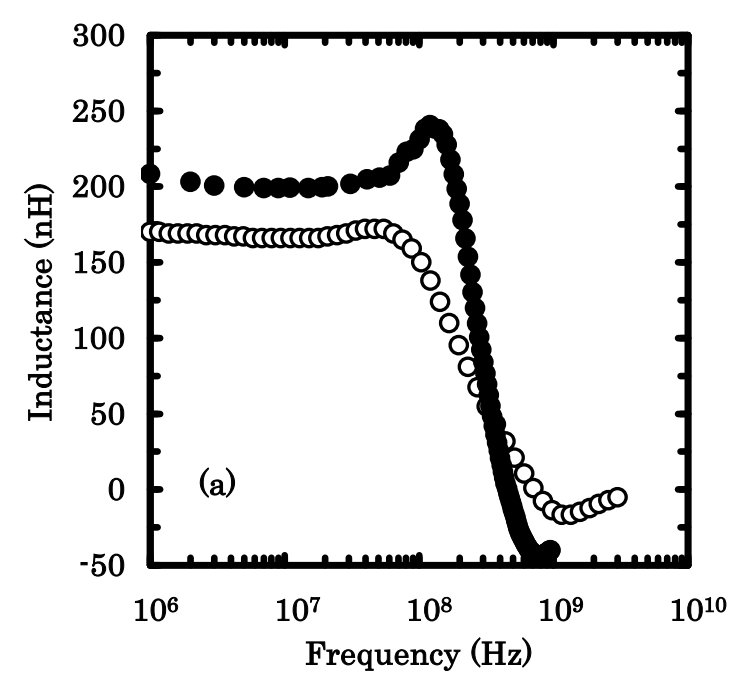

$\mathrm{Li}-\mathrm{Zn}-\mathrm{Cu}$ フェライトに関するインダクタンス・スペクトル [Fig. 5(b)]も， $\mathrm{Ni}-\mathrm{Zn}-\mathrm{Cu}$ フェライトと同様の特徵を有する が, $\mathrm{Ni}-\mathrm{Zn}-\mathrm{Cu}$ フェライトの場合と大きく異なっているのは, 数值計算によって得られたインダクタンス・スペクトルと 実測のスペクトルが定量的にも比較的良好な一致を示した ことである. Fig. 6 では, $\mathrm{Ni}-\mathrm{Zn}-\mathrm{Cu}$ フェライトおよび $\mathrm{Li}-\mathrm{Zn}-\mathrm{Cu}$ フェライトに関する交流抵抗の数值計算結果を, 実測值と比較した. Fig. 6(a)における $\mathrm{Ni}-\mathrm{Zn}-\mathrm{Cu}$ フェライ トの, 実測值, 計算值のいずれも低周波領域ではほぼ 0 を 示しており，ある周波数から急激に立ち上がって急峻な最 大值を示した後に減少するという特徴は類似しているもの の, 両者の值は大きく異なっている. 約 $200 \mathrm{MHz}$ 以下の周 波数領域においては実測值の方が計算值より大きい。逆に それ以上の高周波領域においては，計算值に比へ，実測に おける交流抵抗の最大值が約 $160 \Omega$ (約 36\%) 小さく, 最大 を示す周波数は約 $300 \mathrm{MHz}$ 高いことがわかった. Fig. 6(b) に示された, $\mathrm{Li}-\mathrm{Zn}-\mathrm{Cu}$ フェライトを用いた積層コイルの交 流抵抗スペクトル形状の特徵は, $\mathrm{Ni}-\mathrm{Zn}-\mathrm{Cu}$ フェライトと同 様であるが，インダクタンスの場合と同じく計算と実測さ れたスペクトルが定量的にも良好な一致を示した。

\section{4. 考察}

\section{1 実測値と計算値との一致・不一致について}

$\mathrm{Ni}-\mathrm{Zn}-\mathrm{Cu}$ フェライトを用いた積層コイルにおいて, 計算

Table 2 Material parameters for 3D simulation of a multi-layer chip coil using $\mathrm{Li}-\mathrm{Zn}-\mathrm{Cu}$ ferrite

\begin{tabular}{|l|l|}
\hline Complex permeability of ferrite & $\begin{array}{l}\text { Measured values } \\
\text { (Fig. 3b) }\end{array}$ \\
\hline Complex permittivity of ferrite & $16.6+\mathrm{j} 0$ \\
\hline DC conductivity of ferrite & $5.0 \times 10^{-5} \mathrm{~S} / \mathrm{m}$ \\
\hline DC conductivity of Ag electrode & $4.4 \times 10^{7} \mathrm{~S} / \mathrm{m}$ \\
\hline
\end{tabular}

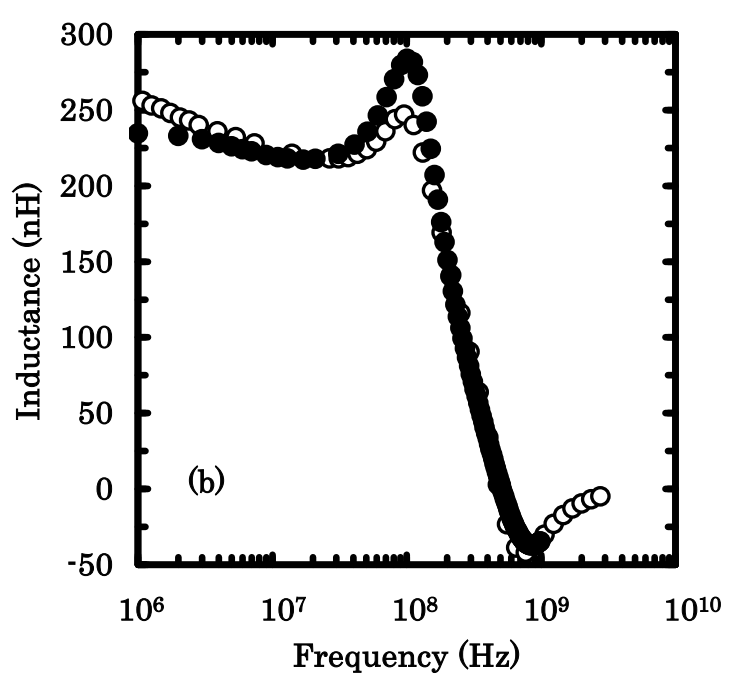

Fig. 5 Inductance spectra of a multi-layer chip coil using (a) Ni-Zn-Cu ferrite and (b)Li- $\mathrm{Zn}-\mathrm{Cu}$ ferrite: open and solid circles denote measured and calculated values, respectively 

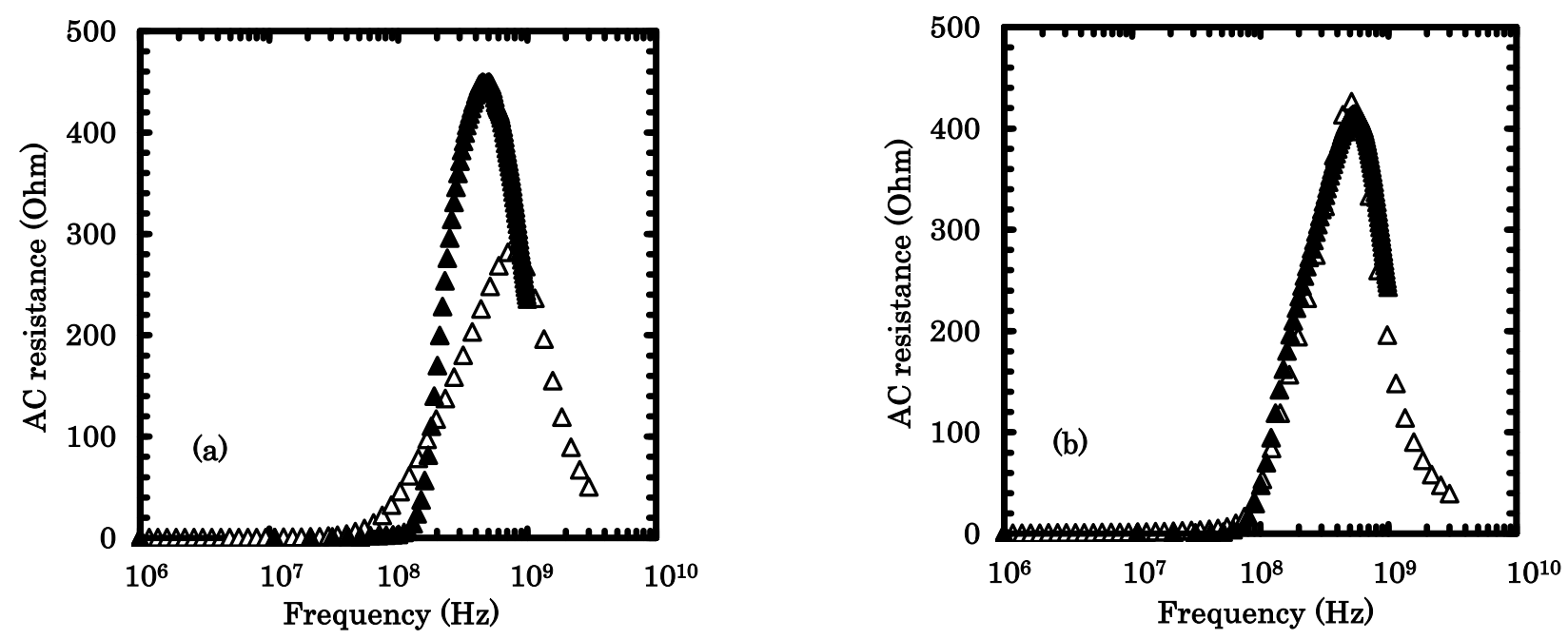

Fig. 6 AC resistance spectra of a multi-layer chip coil using (a) $\mathrm{Ni}-\mathrm{Zn}-\mathrm{Cu}$ ferrite and (b)Li- $\mathrm{Zn}-\mathrm{Cu}$ ferrite: measured values for open triangles and calculated values for solid triangles, respectively

された複素インピーダンス・スペクトルと比ベて実測のス ペクトルでは，主に低周波領域でのインダクタンス，およ び交流抵抗の最大值が減少, 交流抵抗が最大值を示寸周波 数が高周波側へ移行するという特徴が認められた。これら の現象は，インダクタンス・交流抵抗がそれぞれ複素透磁 率の実数部・虚数部に直接関与していることを考慮すると, 以下のように解釈することができる. 低周波領域でのイン ダクタンスの減少および交流抵抗の最大值の減少は, 積層 コイル内部における残留応力によって, 複素透磁率の絶対 值が減少したことに対応している。また，交流抵抗が最大 值を示す周波数が高周波側へシフトした理由については, 積層部品のコイルパターンおよびフェライトの誘電率に依 存した寄生容量と, この積層部品のインダクタンスによる 共振周波数変化の影響が考えられる ${ }^{15,16)}$. 透磁率の絶対值 が低下し，その結果インダクタンスが低下した。一方，フ エライトは強誘電体ではないことからも, 誘電率の残留応 力による変化はごく小さいものと考えられる. 即ち, 残留 応力によってインダクタンスが低下した分だけ共振周波数 が高くなり, その結果, 交流抵抗が最大值を示寸周波数が 高周波側にシフトしたものと考えられる.

このような複素透磁率の絶対值低下は, 多結晶体の微細 構造(結晶粒径, 気孔率)が変化し、磁気的ギャップが発生 したことによる反磁界の影響と類似している ${ }^{17,18)}$. しかし, 内部にコイルパターンを持つ積層部品にした場合と, 内部 にコイルパターンを形成していない場合のフェライト多結 晶体の微細構造を SEM 観察にて比較したが, 両者に顕著 な差は見られず, 両者の差は単に内部にコイルパターンを 持つか否かだけであった。 また, 両積層コイルは, フェラ イト組成が異なる以外は，作製条件，導体ペーストなど同 じである.よって，それぞれの積層コイル内部においては ほぼ同じ残留応力分布が存在していると考えられる．従っ て, $\mathrm{Ni}-\mathrm{Zn}-\mathrm{Cu}$ フェライトにおける計算と実測のスペクトル の違いは, このフェライトの比較的大きな磁歪定数の影響
によるものと考えられる. 一方で, これらの現象は, 上述 のように $\mathrm{Li}-\mathrm{Zn}-\mathrm{Cu}$ フェライトを用いた場合では観測され ない現象であった．多元フェライトの磁歪定数は, 含有す る単元フェライトの $\mathrm{mol}$ 比でほぼ決定することもあり, 用 いた二種のフェライト多結晶体の磁歪定数が冒頭で述べた 文献值の大小関係をほぼ踏襲していることが容易に考えら れる ${ }^{19)}$. 即ち, $\mathrm{Li}-\mathrm{Zn}-\mathrm{Cu}$ フェライトの磁歪定数が,

$\mathrm{Ni}-\mathrm{Zn}-\mathrm{Cu}$ フェライトよりも小さいために, 実効的な複素透 磁率が多結晶体から測定されたものからほとんど変化しな いのである. $\mathrm{Li}-\mathrm{Zn}-\mathrm{Cu}$ フェライトは, 応力に反して複素透 磁率が安定傾向にあることに加え, 他のスピネルフェライ トとは異なり $\mathrm{Ni}-\mathrm{Zn}-\mathrm{Cu}$ フェライトと同等のスヌーク積を 有することから ${ }^{1,2,20)}$, このフェライトを積層部品用の磁性 材料として用いることの優位性が明らかとなった.

残留応力の分布は, コイルの巻き数増加など, 様々な積 層部品の内部導体取り回しによって変化する.また, 焼成 後の冷却条件によってもこの残留応力の分布は変化するも のと考えられる．積層部品のみならず，樹脂モールドや， メッキと微細加工による導体パターンニングなどを用いる 部品でも応力は発生する ${ }^{4)}$.このため, $\mathrm{Ni}-\mathrm{Zn}-\mathrm{Cu}$ フェライ トを用いた電子部品においてはその特性を予測するのは極 めて困難であり，材料特性とコイルパターンから特性を設 計することができない。言い換えれば実際の部品試作を繰 り返す試行錯誤を重ねなければ所望の特性を有した部品が 作製できないということである。これに比べて, $\mathrm{Li}-\mathrm{Zn}-\mathrm{Cu}$ フェライトを部品用の磁性材料として用いると，材料特性 と部品の外寸ルコイル形状から特性を設計することができ, これは実用的あるいは部品の製造という工業的観点からみ ても大きなメリットであると考えられる.

\section{2 複素インピーダンスに及ぼす寄生容量の影響の分離}

積層コイル部品の動作周波数が高くなると, その複素イ ンピーダンス・スペクトルには, 寄生容量による LC 共振 の影響が含まれることを前述した. $\mathrm{Ni}-\mathrm{Zn}-\mathrm{Cu}$ フェライトを 
用いた積層コイルでは，応力による複素透磁率の絶対值低 下の影響により，複素インピーダンスを複素透磁率・コイ ルパターンからの数值計算によって再現できないので, 問 題となる寄生容量の影響を分離して扱うことが困難である。 一方, $\mathrm{Li}-\mathrm{Zn}-\mathrm{Cu}$ フェライトを用いた積層コイルであれば, この寄生容量の影響を容易に分離・把握することができる. ここで指し示す寄生容量とは, Fig. 7 に示すように, 主に 積層コイル内部のコイルターン層間(例えば $\mathrm{C}_{1}$ や $\mathrm{C}_{2}$ ) や, 外 部電極とコイルパターン間 $\left(\mathrm{C}_{3}\right.$ や $\mathrm{C}_{4}$ など $)$ に存在する分布キ ヤパシタンスの合計が, 外部電極間の等価並列キャパシタ ンスとして見積もられるものである.

ここで, $3 \mathrm{D}$ モデルにおける外寸・コイルパターンは変化 させず, 仮想的にフェライトの複素誘電率を変化させるこ とによって複素インピーダンスを数值計算し, 実測の複素 インピーダンスを比較することでこの寄生容量の影響を考 察した例を以下に示す. Fig. 8 および Fig. 9 は, 電磁界シ ミュレーションにおいて, $\mathrm{Li}-\mathrm{Zn}-\mathrm{Cu}$ フェライト多結晶体の 複素誘電率を仮に真空の複素比誘電率 $1.0+\mathrm{j} 0$ と等しいも のとして入力し再計算させたインダクタンスならびに交流 抵抗のスペクトルと, 実測值 $16.6+\mathrm{j} 0$ での結果を併せて示 したものである. Fig. 8 から, $\varepsilon=16.6$ の場合のインダク タンスは約 $200 \mathrm{MHz}$ 付近までは誘電率を変化させてもほ とんど変化しないが，それ以上になると急激に減少傾向が

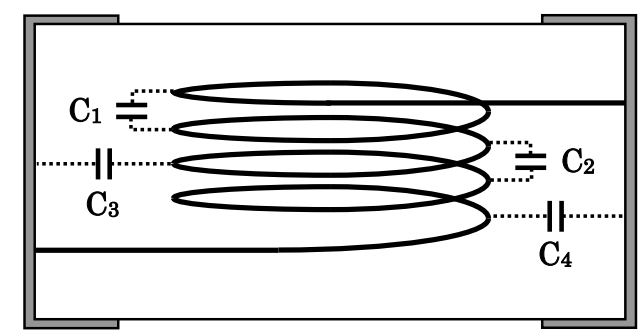

Fig. 7 Schematic view of stray capacitance at the multi-layer chip coil inside

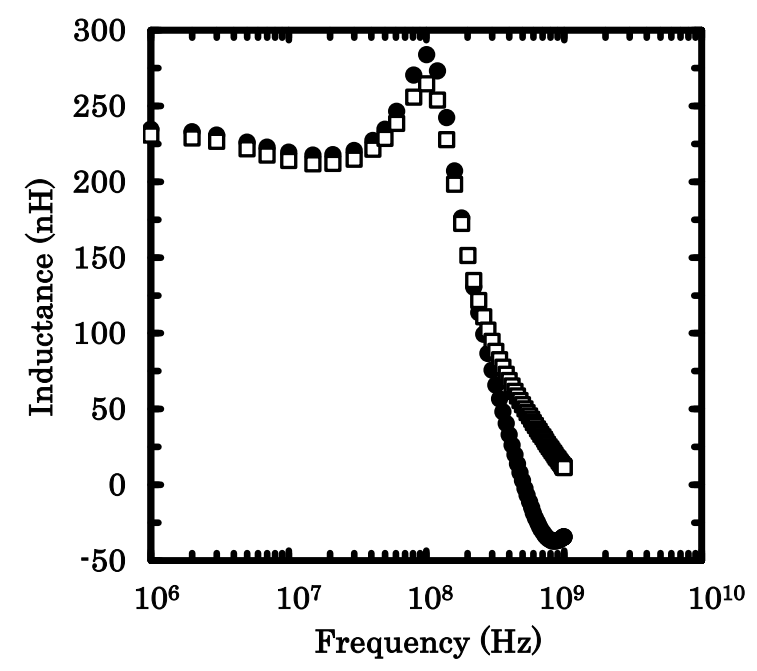

Fig. 8 Calculated inductance spectra of the multi-layer chip coil using $\mathrm{Li}-\mathrm{Zn}-\mathrm{Cu}$ ferrite: $\varepsilon_{\varepsilon}=16.6$ for solid circles and $\varepsilon=1$ for open squares
強くなり，約 $800 \mathrm{MHz}$ で負の極小值を有する. Fig. 9 にお いても, 交流抵抗は約 $200 \mathrm{MHz}$ 付近までは誘電率の影響を 受けないが, それ以上の高周波数領域において $\varepsilon=16.6$ で の絶対值が大きくなり約 $550 \mathrm{MHz}$ で最大值を有する. $\varepsilon$ が 1.0 の場合はピークを示さず単調に増加した.この結果から, これら複素インピーダンス・スペクトルの変化は, まさに 積層コイル部品のインダクタンスと寄生容量による典型的 な並列 LC 共振(自己共振)の影響によるものであることが 明確になる。をを 1 とした計算結果において，インダクタ ンスおよび交流抵抗スペクトルに典型的な共振挙動が見ら れないのは， LC 共振周波数が計算上限の $1 \mathrm{GHz}$ 以上に移 行したことで, 複素透磁率スペクトルのみによる真性の複 素インピーダンス・スペクトルから寄生容量の影響をほぼ 分離できたためと考えられる。このように, $\mathrm{Li}-\mathrm{Zn}-\mathrm{Cu} フ ェ$ ライトを用いた部品では, 多結晶体の複素誘電率を仮に変 化させることで寄生容量を変化させ，その影響について議 論ができる．言い換えれば机上の設計段階でコイル部品の 自己共振周波数設定に役立つのである.

\section{5. まとめ}

$\mathrm{Li}-\mathrm{Zn}-\mathrm{Cu}$ フェライト多結晶体を用いた積層コイルを作 製し, その複素インピーダンス・スペクトルを測定, フェ ライト多結晶体の材料定数・積層コイルの外寸・コイルパ ターンから数值計算した結果と比較した. $\mathrm{Ni}-\mathrm{Zn}-\mathrm{Cu}$ フェラ イトを用いた積層コイルとの大きな違いは, この $\mathrm{Li}-\mathrm{Zn}-\mathrm{Cu}$ フェライト用いた積層コイルの複素インピーダンスの実測 值と計算結果が一致しており，フェライト多結晶体本来の 複素透磁率スペクトルが直接反映することであった。これ は, $\mathrm{Li}-\mathrm{Zn}-\mathrm{Cu}$ フェライトが比較的小さな磁歪定数を有する ため, フェライト多結晶体が内部コイルから受ける残留応 力によっても複素透磁率スペクトルが大きく変化しないた

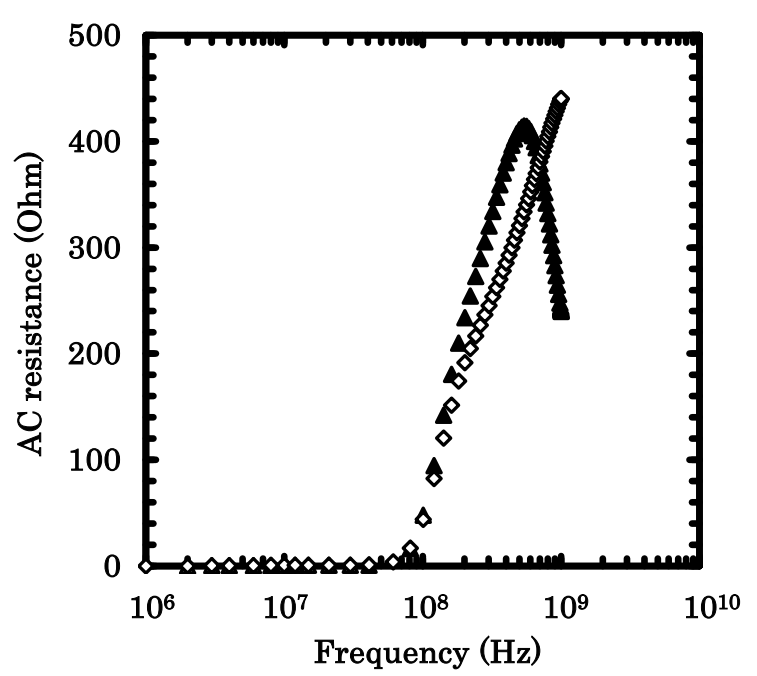

Fig. 9 Calculated AC resistance spectra of the multilayer chip coil using $\mathrm{Li}-\mathrm{Zn}-\mathrm{Cu}$ ferrite: $\varepsilon=16.6$ for solid triangles and $\varepsilon=1$ for open diamond 
めであると考えられる。従って, $\mathrm{Li}-\mathrm{Zn}-\mathrm{Cu}$ フェライトを用 いた電子部品の複素インピーダンス特性が, 数值計算を用 いて比較的容易に見積もることができるということである。 これは, 元来高周波特性に優れ, 環境にも対応した $\mathrm{Li}-\mathrm{Zn}-\mathrm{Cu}$ フェライトの, さらなる大きな優位性である.

謝辞 本研究を遂行するにあたり甚大なるご協力をいただ きました, 姫路工業大学大学院生(現 日新電機株式会社)の 宮本剛氏，および $\mathrm{KOA}$ 株式会社の井上誠, 繁澤功士, 五 味洋二の諸氏に深く感謝の意を表します.

\section{References}

1) T. Nakamura, T. Miyamoto, and Y. Yamada: J. Magn. Magn. Mat., 256, pp.340-347 (2003).

2) T. Miyamoto, T. Nakamura, and Y. Yamada: J. Jpn. Soc. Powder Powder Metallurgy, 50, 8, pp.609-612 (2003). (in Japanese)

3) T. Nakamura, T. Miyamoto, Y. Yamada, M. Naoe, and M. Inoue: Proc. of 9th International Conference on Ferrite (in printing).

4) M. Kumagai, and Y. Ikeda: Proc. of 5th International Conference on Ferrite, pp.625-630 (1989).

5) H. Momoi, A. Nakano, H. Watanabe, and T. Nomura: J. Soc. Mat. Eng. for Resources, 51, 1, pp.54-62 (1992). (in Japanese)

6) A. Nakano, H. Momoi, and T. Nomura: Proc. of 6th International Conference on Ferrite, 41, 6, pp.1225-1228 (1992).

7) A. Nakano, T. Aoki, H. Momoi, T. Suzuki, and T. Nomura:
Proc. of 8th International Conference on Ferrite, pp.1117-1121 (2000).

8) T. Kamiya, A. Nakano, and T. Nomura: J. Jpn. Soc. Powder Powder Metallurgy, 39, 11, pp.999-1004 (1992). (in Japanese)

9) B. Bonnenberg, K. A. Hempel, R. A. Lefever, T. R. McGuire, M. Paulus, H. v. Philipsborn, M. Rubinstein, M. Sugimoto, L. Treitinger, and R. Vautier: Landolt-Börnstein, New Series Group III, 12, b, Ed. K.-H. Hellwege and A. M. Hellwege, (Springer-Verlag Berlin, Heidelberg and New York, 1980), p.93; ibid., p.187.

10) Kaneda, T. Murase, and T. Nomura: J. Jpn. Soc. Powder Powder Metallurgy, 48, 2, pp.136-139 (2001). (in Japanese)

11) T. Sato, S. Ikeda, H. Nakayama, K. Takizawa, and K. Yamasawa: Trans. Magn. Soc. Jpn., 2, 5, pp.377-383 (2002).

12) K. H. Kim, S. Ikeda, M. Yamaguchi, and K. I. Arai: J. Appl. Phys., 93, 10, pp.8588-8590 (2003).

13) L. G. v. Uitert: Proc. of Inst. of Radio Engineers, pp.1294-1303 (1956).

14) P. J. B. Clarricoats: Microwave Ferrites, pp.27-30 (Chapman and Hall Ltd., London, 1961).

15) Y. Mochizuki: Material Integration, 12, 6, pp.21-25 (1999). (in Japanese)

16) M. Yamaguchi, T. Moizumi, M. Baba, K. I. Arai, A. Haga, S. Tanabe, and K. Itoh: J. Magn. Soc. Jpn., 25, 4-2, pp.1095-1098 (2001). (in Japanese)

17) T. Nakamura, T. Tsutaoka, and K. Hatakeyama: J. Magn. Magn. Mat., 138, pp.319-328 (1994).

18) T. Nakamura: J. Magn. Magn. Mat., 168, pp.285-291 (1997).

19) Y. Kikuchi: IEEE Trans. Magn., MAG-4, pp.107-117 (1968).

20) T. Nakamura: J. Appl. Phys., 88, 1, pp.348-353 (2000).

2005 年 4 月 25 日受理, 2005 年 11 月 15 日採録 